\title{
Evaluation of Beta Globin Gene Mutations in Beta Thalassemia Carrier Children in Aydın Province and its Environment
}

\author{
Deniz İlgün$^{1 \oplus}$, Yusuf Ziya Aral ${ }^{2 \oplus}$, Mediha Akcan ${ }^{2 \oplus}$, Özgür Cartı² ${ }^{2}$, Gökay Bozkurt ${ }^{3 \oplus}$
}

${ }^{1}$ Department of Pediatrics, Aydın Adnan Menderes University Medical Faculty, Aydın, Turkey

2 Department of Pediatric Hematology and Oncology, Aydın Adnan Menderes University Medical Faculty, Aydın, Turkey

${ }^{3}$ Department of Medical Genetics, Aydın Adnan Menderes University Medical Faculty, Aydın, Turkey

Cite as: Ilgün D, Aral YZ, Akcan M, Cart Ö, Bozkurt G. Evaluation of beta globin gene mutations in beta thalassemia carrier children in Aydın province and its environment. Trends in Pediatrics 2021;2(1):8-17.

Received: 07 December 2020

Accepted: 13 Febuary 2021

Publication date: 30 March 2021

Keywords: Beta thalassemia carrier, complete blood count parameters, beta globin gene mutations, hemoglobin electrophoresis

\section{Yusuf Ziya Aral}

Department of Pediatric Hematology and Oncology, Aydın Adnan Menderes University Medical Faculty, Aydın, Turkey

ORCID: 0000-0001-7964-6266

yuziar_12@yahoo.com

D. Ilgün 0000-0002-0823-1327

M. Akcan 0000-0003-4956-7916

Ö. Cart 0000-0002-7604-6481

G. Bozkurt 0000-0002-6963-3186

\section{ABSTRACT}

Objective: Beta thalassemia carriers (BTC) in Turkey is observed with a frequency of $2.1 \%$, and it is the most common cause of anemia after iron deficiency. There are few studies showing the effect of genotype on phenotype in beta thalassemia carrying children. The aim of this study is to determine the mutation diversity of these children in and around Aydin and evaluate the effects of these mutations on complete blood count parameters and hemoglobin electrophoresis.

Methods: This study included mutation analysis of 65 patients who were diagnosed as BTC in Adnan Menderes University, Faculty of Medicine, Department of Child Health and Diseases, Pediatric Hematology Outpatient Clinic between 01.01.2014 and 01.08.2019. Complete blood count, hemoglobin electrophoresis and mutation analysis results were obtained from the computer data system and patient files. Research data were evaluated by using SPSS 21.0 statistics program.

Results: The study population with a mean age $8.34 \pm 4.94$ years consisted of 39 (60.0\%) male, and $26(40.0 \%)$ female patients. When full blood count parameters were analyzed, $87.7 \%$ of the patients had anemia, 100\% microcytosis and high red cell distribution width (RDW), $49.2 \%$ hypochromia and $87.7 \%$ increased red blood cell (RBC) counts. RDW level was $\geq 16 \%$ in $66.2 \%$ of the cases. Seventeen different mutations were detected. The mutations most frequently occurred in "intron 1" gene region (66.1\%). The most common mutations were heterozygous IVS I-110 mutation in $44.11 \%$, heterozygous IVS I-1 G>A mutation in $8.8 \%$, heterozygous IVS I-6 T>C mutation in $7.5 \%$ and IVS $11-745$ mutation in $7.5 \%$ of the patients. RDW level was $\geq 16 \%$ in $66.2 \%$ of the cases. Seventeen different mutations were detected. The mutations most frequently occurred in "intron 1" (66.1\%) gene region. Most commonly IVS I-110 (44.11\%), heterozygous IVS I-1 G>A (8.8\%) heterozygous IVS I-6 T>C (7.5\%) and IVS II-745 (7.5\%) mutations were observed. In patients with IVS I-110 mutation, average values for $\mathrm{Hb}$ (10.55 gr/dL), MCV (58.44 fL), RDW (16.51\%), RBC (5680×10\%/L), HbA2 (4.77\%), HbF (2.34\%) were as indicated. Mutations detected in 12 patients with HbF level above $5 \%$ including: cases with IVS I-110 ( $n=5)$ mutations, heterozygous IVS I-6 T>C, Codon 39 C > T IVS I-116, c.25-26 del AA (plys9Valfs), c.27dupG (pSer10valfs*14), c316-373 (IVS II-478 $C>A$, and $-87 C>T$ mutations. Mentzer index was calculated as $>13$ in six patients $(9.2 \%)$. The mutations seen in these patients were IVS-I 110, c.27dupG (p.Ser10valfs*14), c316-373 (IVS II-478 C>A heterozygotes, and $-87 \mathrm{C}>T$ heterozygotes. There were four patients (6.1\%) with a RDW index of $>220$. Two of these patients had c.27dupG (p.Ser10valfs*14) and others had heterozygous c316-373 (IVS II-478 $C>A$ and $-87 C>$ T mutations. Mutations detected in four patients with $\mathrm{HbF}$ levels in the range of 9.48-15.67 and the patients had heterozygous IVS I-116 T>G, IVS I-110 G>A, c.25-26 del AA (p.lys59valfs), and c27 dupG (pSer10 valfs*14) mutations, and three of these mutations carrying $b^{\circ}$ mutation type were located in exon 1 and one of them carrying $\mathrm{B}^{+}$mutation type (IVS I-110) in intron 1.

Conclusion: The same mutations detected in patients with beta thalassemia carriers have different effects on complete blood count parameters. $\mathrm{HbA2}$ and $\mathrm{HbF}$ levels which suggests that these mutations are not effective on the phenotype alone and there may be additional factors which should be clarified. We think that there may be BTC in cases with low RBC, Mentzer index of $\geq 13$ and RDW index of $\geq 220$, $H b A 2<3.5$ and studying the mutation analysis of these patients will contribute significantly to the literature. 


\section{INTRODUCTION}

Thalassemia is a hemoglobin $(\mathrm{Hb})$ disorder characterized by a decrease in the synthesis of one or more globin chains. ${ }^{1}$ The disorders which occur due to this decrease or inability to make the globin chain are classified as alpha $(\alpha)$ and beta $(\beta)$ thalassemias. ${ }^{2}$

It is the single most common gene disease in the world, characterized with hemolytic anemia, microcytosis and shows autosomal recessive transition. There are approximately 270 million thalassemia carriers in the world. ${ }^{1}$

Generally, beta thalassemia is classified in two types as $\beta^{\circ}$ and $\beta^{+}$thalassemia. Rarely, a form that is lighter than these two alleles is also shown as $\beta^{++}$ and causes minimal deficiency in $\beta$ chain production. Beta thalassemia carriers (BTC) are clinically asymptomatic. Studies conducted all around Turkey reveal that an average of $2.1 \%$ of the population is BTC and this rate extends to $10 \%$ in some regions. ${ }^{3,4}$ Heterozygotes can be diverse. It has been shown that individuals with type $\beta^{0}$ thalassemia have a lower erythrocyte volume (MCV) than those with type $\beta^{+} .^{5}$ In cases with heterozygous thalassemia, $\mathrm{HbF}$ levels, like $\mathrm{HbA} 2$, differ according to the mutation types. And $\mathrm{HbF}$ values were found to be higher in studies conducted in the $\beta^{\circ}$ group.

Complete blood count and peripheral blood smear examination are guiding, simple and fast terminating tests particularly in the initial evaluation of patients with anemia, in the differential diagnosis and in the selection of tests to be requested later. Additionally, hematological tests such as erythrocyte indices, hemoglobin electrophoresis are also carried out. ${ }^{1}$ In addition, $\mathrm{MCV}$, mean corpuscular hemoglobin $(\mathrm{MCH})$ per erythrocyte and $\mathrm{Hb}$ are useful variables for screening hemoglobinopathy. For the diagnosis of thalassemia, results of electrophoresis and $\mathrm{Hb}$ values, types of $\mathrm{Hb}$ and abnormal $\mathrm{Hb}$ should be revealed. ${ }^{2}$

Beta globin is a relatively small and structurally simple gene. It is located in the globin gene cluster on the short branch of the $11^{\text {th }}$ chromosome (11p 15.5). Mutations in the globin gene on the developmental process to $\mathrm{Hb}$ have the potential to result in $\beta$-thalassemia, sickle cell anemia, or formation of an abnormal $\mathrm{Hb}^{6}{ }^{6}$ Detection of $\beta$ globin gene mutations is required for early prenatal diagnosis of $\beta$-thalassemia or identification and treatment projects of carriers of heterozygous mutations. ${ }^{2}$ In BTC, the effect of genotype on phenotype is considered inevitable. Since the carriers in the society have normal appearance, they cannot be detected unless thalassemia tests are performed. In areas where the risk of thalassemia is high, the carriers should be identified with community screening.

The aim of this study is to determine the mutation diversity in children with BTC status in Aydın and its surroundings and to evaluate the effects of these mutations on hemoglobin electrophoresis.

\section{MATERIALS and METHODS}

In this retrospective study, 65 patients without iron deficiency accepted as BTC whose diagnoses were confirmed by mutation analysis in Adnan Menderes University Faculty of Medicine Department of Child Health and Diseases, Pediatric Hematology Outpatient Clinic between January 2014 and August 2019 were included.

Ethics committee approval was obtained from Adnan Menderes University Medical Ethics Committee. Complete blood count parameters and $\mathrm{HbA} 2$ level at the time of diagnosis of these cases were obtained from file scans and computer data system. Parameters determined by whole blood count analysis were calculated with Mentzer index [MCV/red blood cell $(\mathrm{RBC})]$ and red cell distribution width (RDW) index (MCVxRDW/RBC) formulas. Mentzer index of $<13$, RDW index of $<220$ were interpreted in favor of thalassemia carrier status. For $\mathrm{HbF}$ values, $<1 \%$ was considered normal, 1-5\% slightly high and $>5 \%$ high. ${ }^{7}$ Research data were evaluated by using SPSS 21.0 statistics program. The fitness of continuous variables to normal distribution was investigated using the Kolmogorov-Smirnov test. For the descriptive statistics of the study, the data fitting the normal distribution, were expressed as mean and standard deviation, and those that did not fit the normal distribution as median, minimum and maximum values. In the study, chi-square test was used to show whether there is a difference between 
categorical variables. ANOVA was used to compare the parametric properties of continuous variables in independent groups, and the Kruskal- Wallis Test was used to compare those that do not have the parametric properties of continuous variables in independent groups. $P$ value less than 0.05 was accepted as the level of statistical significance.

\section{RESULTS}

Of the 65 patients included in this study, 39 (60.0\%) were male, $26(40.0 \%)$ were female and the mean age was $8.34 \pm 4.94$ years (range 1.0-18.0). Mean values for $\mathrm{Hb} 10.55 \pm 1.07 \mathrm{gr} / \mathrm{dL}$ (range, 8.00-13.10), RBC $5580 \pm 538 \times 10^{9} / \mathrm{L}$ (range, 3300-6670), MCV $59.38 \pm 5.48 \mathrm{fL}$ (range, 47.50-74.60), MCH 18.77 \pm 1.96 pg (range, 14.10-24.70), MCHC 31.85 $\pm 0.94 \mathrm{pg}$ (range, 29.6-33.8), platelet (plt) count (387.58 $\left.\pm 120.04 \times 10^{9} / \mathrm{L}\right)$ (range, 215.0-787.0), hematocrit (Hct) $33.00 \pm 3.31 \%$ (range, 27.0-43.4), RDW 16.95 $\pm 2.63 \%$ (range, 14.0-32.9), HbA2 $4.75 \pm 0.86 \%$ (range, 2.42-6.70), HbF $2.80 \pm 3.28 \%$ (range, 0.00-15.67) were as indicated. Complete blood count parameters and results of electropheresis are presented in Table 1.

Seventeen different mutations were detected in the patients. The four most common ones were heterozygous IVS I-110 G>A (44.11\%), IVS I-1 G>A (8.82\%), IVS I-6 T>C (7.35\%) mutations and IVS II-745 mutation (7.35\%). The distribution and frequency of all detected mutations are reflected in Table 2 .

Table 1. Complete blood count parameters and $\mathrm{HbA} 2$ and $\mathrm{HbF}$ levels

\begin{tabular}{|c|c|c|c|c|c|c|}
\hline & n & Mean & Median & Minimum & Maximum & SS* \\
\hline $\mathrm{Hb}(\mathrm{gr} / \mathrm{dL})$ & 65 & 10.55 & 10.60 & 8.00 & 13.10 & 1.07 \\
\hline $\operatorname{RBC}(10 \% / \mathrm{L})$ & 65 & 5580 & 5640 & 3300 & 6670 & 538 \\
\hline $\mathrm{MCV}(\mathrm{fL})$ & 65 & 59.38 & 59.00 & 47.50 & 74.60 & 5.48 \\
\hline $\mathrm{MCH}(p g)$ & 65 & 18.77 & 18.55 & 14.10 & 24.70 & 1.96 \\
\hline $\mathrm{MCHC}(\mathrm{gr} / \mathrm{dL})$ & 65 & 31.85 & 31.95 & 29.60 & 33.80 & .94 \\
\hline Platelet $(10 \% / \mathrm{L})$ & 65 & 387.58 & 364.50 & 215.00 & 787.00 & 120.04 \\
\hline Hct (\%) & 65 & 33.00 & 33.20 & 27.00 & 43.40 & 3.31 \\
\hline RDW (\%) & 65 & 16.95 & 16.25 & 14.00 & 32.90 & 2.63 \\
\hline $\mathrm{HbA} 2(\%)$ & 65 & 4.75 & 4.73 & 2.42 & 6.70 & .86 \\
\hline $\mathrm{HbF}(\%)$ & 65 & 2.80 & 1.80 & .00 & 15.67 & 3.28 \\
\hline
\end{tabular}

*SD: Standard Deviation

Table 2. Mutation distribution and frequency

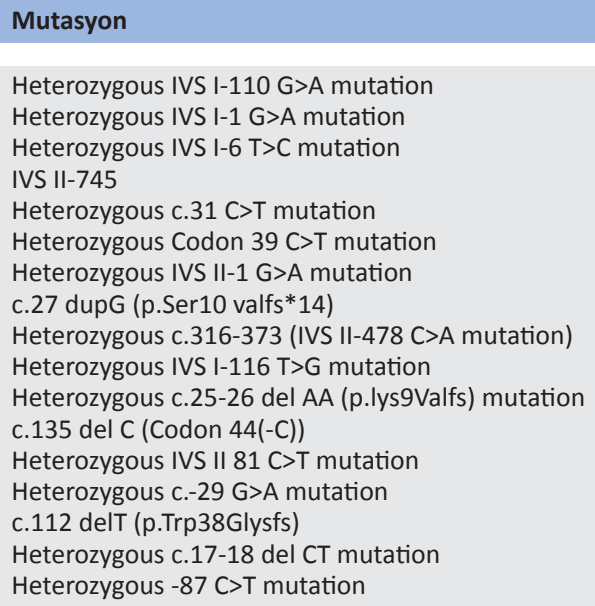


Table 3. Mutations and gene regions

Mutation
Heterozygous IVS I-110 G>A mutation
Heterozygous IVS I-1 G>A mutation
Heterozygous IVS I-6 T>C mutation
Heterozygous IVS I-116 T>G mutation
Total

\section{Mutation}

\section{IVS II-745}

Heterozygous IVS II-1 G>A mutation

Heterozygous c.316-373 (IVS II-478 C>A mutation)

Heterozygous IVS II 81 C >T mutation

Total

\section{Mutation}

Heterozygous c.31 C>T mutation

Heterozygous c.25-26 del AA (p.lys9Valfs) mutation

c. 27 dupG (p.Ser10 valfs*14)

Heterozygous c.-29 G>A mutation

Heterozygous c.17-18 del CT mutation

Heterozygous $-87 \mathrm{C}>\mathrm{T}$ mutation

Total

\section{Mutation}

Heterozygous Codon 39 C>T mutation

c.112 delT (p.Trp38Glysfs)

c.135 del C (Codon 44(-C))

Total

IVS II-745 mutation was detected in five patients. Three of these patients were accompanied by the heterozygous c. $31 \mathrm{C}>\mathrm{T}$ mutation. Therefore, although 65 patients were included in this study, 68 mutations were detected.

Mean $\mathrm{Hb}$ level of the patients was $10.55 \pm 1.09 \mathrm{gr} / \mathrm{dL}$ (range: 8.0-13.0) in those with a heterozygous IVS I-110 G>A mutation; 10.17 $\pm 0.81 \mathrm{gr} / \mathrm{dL}$ (range, 9.011.3) for heterozygous IVS I-1 G>A mutation; $10.96 \pm 0.55 \mathrm{gr} / \mathrm{dL}$ (range, 10.2-11.5) for heterozygous IVS I-6 T>C mutation and $10.34 \pm 0.69 \mathrm{gr} / \mathrm{dL}$ (range, 9.5-11.1) for IVS II-745 mutation. There was no statistically significant difference between mean $\mathrm{Hb}$ levels among patients $(p=0.408)$.

Mean Hct level of the patients was $33.11 \pm 3.53$ (range, 27.00-43.40) in those with heterozygous IVS I-110 G>A mutation; $31.62 \pm 2.50$ (range, 27.70-35.20) in those with IVS I-1 G>A, 33.84 2 .64 (range, 31.0036.50) in IVS I-6 T>C patients with heterozygous mutation; $32.24 \pm 2.99$ (range, 28.00-35.50) in IVS

\begin{tabular}{|c|}
\hline $\mathbf{n}$ \\
\hline 30 \\
6 \\
5 \\
2 \\
43 \\
\hline
\end{tabular}

\begin{tabular}{|c|}
\hline$\%$ \\
\hline 69.7 \\
13.9 \\
11.6 \\
4.6 \\
100.0 \\
\hline
\end{tabular}

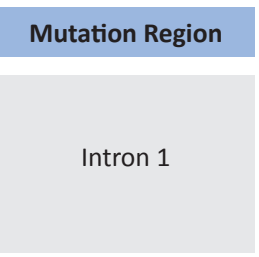

\begin{tabular}{|c|}
\hline $\mathbf{n}$ \\
\hline 5 \\
2 \\
2 \\
1 \\
10 \\
\hline
\end{tabular}

\begin{tabular}{|c|}
\hline$\%$ \\
\hline 50.0 \\
\hline 20.0 \\
20.0 \\
10.0 \\
100.0 \\
\hline
\end{tabular}

Mutation Region

\begin{tabular}{|c|}
\hline $\mathbf{n}$ \\
3 \\
2 \\
2 \\
1 \\
1 \\
1 \\
10
\end{tabular}

\begin{tabular}{|c|}
\hline$\%$ \\
\hline 30.0 \\
20.0 \\
20.0 \\
10.0 \\
10.0 \\
10.0 \\
100.0 \\
\hline
\end{tabular}

Mutation Region

\begin{tabular}{|l|}
\hline $\mathbf{n}$ \\
\hline 3 \\
1 \\
1 \\
5
\end{tabular}

\begin{tabular}{|c|}
\hline$\%$ \\
\hline 60.0 \\
\hline 20.0 \\
20.0 \\
100.0 \\
\hline
\end{tabular}

Intron 2

Exon 1

II-745 heterozygous mutation. There was no statistically significant difference between mean Hct levels $(p=0.544)$.

Mean RBC level of the patients was $5680 \pm 3840 \times 10 \% / \mathrm{L}$ (range, 4880-6520) in those with heterozygous IVS I-110 G>A mutation; 5780 $\pm 2960 \times 10 \%$ L (range, 55606360) in heterozygous IVS I-1 G>A, mutation; $5400 \pm 2450 \times 10 \%$ (range, 5050-5660) in heterozygous IVS I-6 T>C mutation; 5460 $\pm 4880 \times 10 \%$ L (range, 48306010), and in heterozygous IVS II-745 mutation. There was no statistically significant difference between mean RBC levels ( $p=0.170)$.

Mean RDW level of the patients was $16.51 \pm 1.29$ (range, 14.90-19.60) in those with heterozygous IVS I-110 G>A mutation; 16.88 \pm 1.51 (range, 15.40-19.40) in heterozygous IV mutation; $15.50 \pm 1.18$ (range, 14.10-17.10) in heterozygous IVS I-6 T>C mutation and 16.25 \pm 1.16 (range, 15.00-17.80) in IVS II-745 mutation. There was no statistically significant difference between mean RDW values $(p=0.326)$. 
Mean $\mathrm{HbA} 2$ level of the patients was $4.77 \pm 0.71$ (range, 3.70-6.70) in those with a heterozygous IVS I-110 G>A mutation; $5.02 \pm 0.98$ (range, 3.50-6.10) in heterozygous IVS I- $1 \mathrm{G}>\mathrm{A}$ mutation, $4.39 \pm 0.71$ (range, 3.40-5.24) in heterozygous IVS I-6 T $>C$ mutation and $5.00 \pm 0.73$ (range, 4.40-6.10) in IVS II-745 mutation. There was no statistically significant difference between mean $\mathrm{HbA2}$ values $(\mathrm{p}=0.424)$.

Mean HbF level of the patients was $2.34 \pm 2.94$ (range, 0.00-13.32) in those with heterozygous IVS I-110 G>A mutation; $1.35 \pm 1.48$ (range, 0.00-3.70), $1.83 \pm 3.00$ (range $0.00-6.90$ ) in heterozygous IVS I-1 $\mathrm{G}>\mathrm{A}$ mutation; $1.83 \pm 3.00$ (range $0.00-6.90$ ) in heterozygous IVS I- 6 T>C mutation and $2.44 \pm 1.66$ (range, 0.00-4.00) in IVS II-745 mutation. There was no statistically significant difference between mean HbF values $(p=0.726)$.

When 68 mutations determined in 65 patients were examined according to RDW indexes, it was $>220$ in four mutations $(5.88 \%)$ and $\leq 220$ in 64 mutations (94.11\%).

When mutations with low RDW indexes were examined, two (50\%) were c.27 dupg (p. Ser10 valfs*14) mutation, one was (25\%) c.316-373 (heterozygous IVS II-478 C>A) mutation and one (25\%) was identified as a heterozygous $-87 \quad C>T$ mutation. None of these patients had iron deficiency anemia. The RDW indexes of both patients (100\%) with c.27 dupG (p.Ser10 valfs*14) mutation were $>220$. Four most common mutations among all were heterozygous IVS I-110 G>A ( $n=30)$, IVS I- 1 G $>A$ $(n=6)$, IVS I-6 T>C $(n=5)$ mutations and RDW index was $\leq 220$ in all patients with IVS II-745 $(n=5)$ mutations. When the relationship of mutations with $\mathrm{HbF}$ was examined, $\mathrm{HbF}$ value was zero in 21 mutations (30.88\%), between $0-1$ in 3 mutations (4.41\%), between $1-5$ in 32 mutations (47.05\%) and greater than five in 12 mutations (17.64\%). When the most frequently seen heterozygous IVS I-110 $\mathrm{G}>\mathrm{A}$ mutation $(\mathrm{n}=30)$ was evaluated, the most common $\mathrm{HbF}$ values were between 1-5 (43.33\%). Among the three most common mutations, $\mathrm{HbF}$ values detected in patients with heterozygous IVS I-1 G>A ( $n=6)$ and IVS II-745 ( $n=5)$ mutations were mostly between $1-5(50 \%, 80 \%$, respectively) whereas $\mathrm{HbF}$ values in 5 cases with heterozygous IVS I- $6 \mathrm{~T}>\mathrm{C}$ mutation were mostly zero (60\%).

As for the relationship of mutations with the $\mathrm{MI}$, four most common mutations were heterozygous IVS I-110 G>A ( $n=30)$, IVS I-1 G>A ( $n=6)$, and IVS I-6 T>C $(n=5)$ mutations and mean Mentzer indexes of IVS II-745 $(n=5)$ were $10.34 \pm 1.18,9.46 \pm 0.82,11.8 \pm 0.41$ and $11.37 \pm 1.73$, respectively. The mutations with mean $\mathrm{MI}$ value above 13 were heterozygous IVS I-110+-87 C>T (16.94\%), IVS II-81 C>T (14.49\%), c.316-373 (IVS II-478 C>A) (13.52 \pm 1.65$)$ and c.27 dupG (p.Ser10 valfs*14) (14.72 \pm 3.22$)$ mutations. Sixty-one (89.7\%) of all mutations were detected in Aydın province. Five of them were in Muğla, one was in İmir and one in Denizli.

When the gene regions of 68 mutations were analyzed, $43(63.3 \%)$ were detected in intron 1, 10 (15.87\%) in intron 2 region, 10 (15.87\%) in exon 1 and five $(7.93 \%)$ in exon 2 regions. The most common mutation was heterozygous IVS I-110 G>A mutation $(n=30)$, followed by heterozygous IVS I- $1 \mathrm{G}>A(n=6)$ mutations and IVS I- 6 T>C mutations $(n=5)$ were detected in intron 1 region. Exon $2(n=5 ; 7.93 \%)$ was determined as the least common gene mutation region and $60 \%$ of the mutations in this region are heterozygous Codon $39 \mathrm{C}>\mathrm{T}$ mutations.

\section{DISCUSSION}

BTC is the most common single gene disease in the world, and $4.5 \%$ of the world population carries a mutation in the globin chain. ${ }^{8,9}$ Due to its geographical location, Turkey has been affected by a large number of societies and mutations of different types have been detected. ${ }^{10,11}$ Since the carrier rate of thalassemia is $5.1 \%$ in Aydın, evaluation of mutation diversity in this province and determination of the frequent mutations have a vital importance for public health. ${ }^{10} \mathrm{Hb}$ as one of the complete blood count parameters, may be normal or low in individuals with BTC. ${ }^{12} \mathrm{Hb}$ level over $8 \mathrm{gr} / \mathrm{dL}$ is generally observed in thalassemia carriers. In cases with lower Hb levels, investigation of additional factors contributing to anemia is recommended. ${ }^{13}$ The patients without iron deficiency had $\mathrm{Hb}$ levels between 8-13 $\mathrm{gr} / \mathrm{dL}$ and $87.7 \%$ of them had anemia. Hb levels of $>8 \mathrm{gr} / \mathrm{dL}$ suggested that there is no additional factor contributing to anemia. MCV level lower than normal 
is an indicator of microcytosis. Thalassemia trait is the most common cause of microcytic anemia after iron deficiency anemia. Different MCV levels have been reported in BTC as follows: 60-79 fL [Aksoy et al. ${ }^{14}$ ], 59-83fL [Arpacl et al. ${ }^{15}$ ], 60-71 fL [Tanriverdi et al. ${ }^{16}$ ], 65-82 fL [Topal ${ }^{17}$ ], and 56-71 fL [Evrensel $\left.{ }^{18}\right]$. In this study, MCV levels ranged between 47.5-74.6 fL which were found to be lower than normal in all the patients.

RDW level is increased in iron deficiency anemia and normal or slightly higher in BTC. ${ }^{19}$ It has been stated that RDW is a more sensitive parameter in the diagnosis of mild iron deficiency anemia than the saturations of serum iron, ferritin and transferrin. ${ }^{12}$ It is stated that iron deficiency is the most common reason of the rise in RDW. RDW may increase in thalassemia, other hemoglobinopathies and other conditions causing microcytosis. ${ }^{20}$ Cook et al. ${ }^{21}$ accepted ferritin as a more sensitive test compared to RDW in iron deficiency anemia and specified that it is an important parameter especially in the diagnosis of those who did not receive iron treatment priorly. In this study, normal values of RDW were not detected in patients without iron deficiency. The fact that RDW of $22 \%$ were slightly higher $(<16.0)$ and RDW of $66.2 \%$ was higher $(\geq 16)$ suggests that this parameter is not an essential parameter in differential diagnosis.

RBC counts are often increased in thalassemia carriers. RBC levels may be low, normal or high in iron deficiency anemia. ${ }^{22}$ In their study conducted in 1999 on 195 patients with iron deficiency anemia and 463 cases with beta thalassemia carriers, Madan et al. ${ }^{23}$ reported that $\mathrm{RBC}$ increased in the group with thalassemia carriers, but they did not find any significant difference. In this study, RBC counts were increased in $87.7 \%$, and decreased in $12.3 \%$ of the patients. Mutations detected in patients with low RBC counts were as follows: heterozygous c27dupG, IVS I-110 G>A IVS I-6 T>C, IVS II-745, IVS I-116 T>G and c.316-373 (IVSII-478 C>A mutations. In the literature, we did not find any study based on mutation examination in patients with low RBC counts. We think that patients with low RBC counts may also have thalassemia trait, and studying the mutation analysis of these patients having thalassemia trait will make a significant contribution to the literature.
In addition to RDW, RBC, MCV values, Mentzer and RDW indexes are frequently used in the differential diagnosis of BTC and iron deficiency anemia. ${ }^{22}$ Mentzer index was found to be $95 \%$ sensitive in terms of differentiating beta thalassemia carrier status. ${ }^{24}$ While $\mathrm{Ml}$ is below 13 in BTC, this value is $\geq 13$ in iron deficiency anemia. Oğuz et al. ${ }^{22}$ reported MI levels between 7.00-12.20 in pediatric BTC. Rahim et al. ${ }^{24}$ stated that they diagnosed BTC in 55 patients with $\mathrm{Ml}<13$ and 4 patients with $\geq 13$ whereas Demir et al. ${ }^{19}$ submitted that MI was not sensitive and specific in the differential diagnosis. MI level in our patients was between 8.30-17.0 and there were 6 patients $(\geq 13)$ whose $\mathrm{Ml}$ did not suggest the presence of a thalassemia trait. The mutations we detected in these patients were heterozygous IVS-I 110, c.27dupG (p.Ser10valfs*14), c316-373 (IVS II-478 C>A, and -87 C>T mutations. In the literature, no study was found examining the relation between $\mathrm{BTC}$ mutations with the $\mathrm{MI}, \mathrm{RDW}$ index and $\mathrm{RBC}$ which are among the most reliable parameters used in the differentiation between iron deficiency anemia and BTC status. Demir et al. ${ }^{19}$ suggested that RDW index is the second most effective parameter in the differential diagnosis of iron deficiency anemia and BTC in children. Vehapoğlu et al. ${ }^{25}$ found RDW index $<220$ in $83 \%$ of patients with BTC. Examination of RDW indexes based on mutations in this study, revealed RDW index as $<220$ in $94.1 \%$ of the patients. There were 4 patients whose RDW indexes did not suggest the presence of a thalassemia trait (RDW index 2220 ). HbA2 level $>3.5 \%$ in $\mathrm{Hb}$ electrophoresis is diagnostic in cases where thalassemia carrier status is considered based on complete blood count parameters. $\mathrm{HbA} 2$ values were between 4.5-5.8\% in Oğuz et al's study ${ }^{22}, 1.5$ $5.6 \%$ in Evrensel's study, and 3.8-7.5\% in Mumbai and $3.5-7.5 \%$ in Delhi in Madan et al's study. ${ }^{23}$ Mean $\mathrm{HbA} 2$ value of the patients was $3.7 \%$ in the studies by Topal ${ }^{17}$ and Öney et al. ${ }^{1}$ where they found the smallest $\mathrm{HbA} 2$ value as $3.77 \%$. In this study, the lowest, and the highest $\mathrm{HbA} 2$ values were $2.42 \%$ and $6.7 \%$, respectively. The $\mathrm{HbA} 2$ level was $\geq \% 3.5$ in $93.8 \%$ of the patients, and $<\% 3.5$ in $6.1 \%$ of the patients. In the literature, complete blood count index suggesting BTC, with normal MCV and $\mathrm{HbA} 2$ level in mutations such as IVS I-6 T>C, codon $27 \mathrm{G}>\mathrm{T}$, LCR deletion in silent BTC have been reported. In the study of Galanello et al. ${ }^{26},-101$ C $>$ T, IVS I-6 T>C 
mutations were more frequently associated with normal or borderline $\mathrm{HbA} 2$ values. Decreased production of delta globin chains may cause normalization of $\mathrm{HbA} 2$ levels. ${ }^{41}$ In this study, delta gene mutation was not examined and there were no children with iron deficiency anemia. The mutations we detected in patients with normal $\mathrm{HbA} 2$ levels were heterozygous $\mathrm{HbA} 2$ value $-87 \mathrm{C}>\mathrm{T}$, IVS II $81 \mathrm{C}>\mathrm{T}$, IVS I-6 T>C, c316-373 (heterozygous IVS II-478 C>A) mutations. After investigating the presence of delta mutations, it was thought that whether these mutations progressed with normal $\mathrm{HbA} 2$ levels could be interpreted more accurately.

We had mean $\mathrm{HbA} 2$ level of $4.77 \pm 0.71$ in patients with heterozygous IVS I-110 G>A mutation, 5.02 \pm 0.98 in heterozygous IVS I-1 G>A mutation, 4.39 \pm 0.71 in heterozygous IVS I- 6 T $>C$ mutation and $5.00 \pm 0.73$ in heterozygous IVS II-745 mutation. There was no statistically significant difference between mean HbA2 values $(p=0.424)$.

Approximately half of the BTC have normal $\mathrm{HbF}$ levels, whereas in the other half $\mathrm{HbF}$ levels are slightly increased. ${ }^{13}$ Higher $\mathrm{HbF}$ can be seen in cases in the presence of promoter region mutation, alpha gene triplication and delta gene mutation. ${ }^{27}$ Öney et $\mathrm{al}^{1}$ found mean $\mathrm{HbF}$ levels of $84 \mathrm{BTC}$ as $2.64 \%$ (range $0-8.5 \%$ ) and suggested that this may be caused by $\beta^{\circ}$ mutation type. Macaulay ${ }^{27}$ suggested in his study that very few cases had $\mathrm{HbF}$ values between $4-15 \%$, most of which may be related to the transport of the hereditary persistent $\mathrm{HbF}$ gene. In this study, $\mathrm{HbF}$ value was normal in $35.3 \%$, slightly high in $46.1 \%$ (1-5\%), and high in $18.4 \%$ (>5\%) of the cases. In $40 \%$ of the patients with, heterozygous IVSI-110 G>A mutation, $\mathrm{HbF}$ was between $1-5 \%$ and $>5$ in $41 \%$ of the patients. None of the patients with IVS I-1 G>A mutations had $\mathrm{HbF}$ values above $5 \%$. Unlike our study, Kutlar et al. ${ }^{28}$ detected high $\mathrm{HbF}$ values in IVS I-1 and IVS I-II. The highest HbF levels in our study were $9.48 \%, 9.7 \%, 13.32 \%, 15.67 \%$, and mutations detected in these individuals were heterozygous IVS I-116 T>G, c.25-26 del AA (p.lys59valfs), IVS I-110 $\mathrm{G}>\mathrm{A}$ mutations, and nonsense mutation of $c .27$ dupG (p.Ser10 valfs*14) respectively. Three of these mutations had a $\beta^{\circ}$ mutation type, three were in exon 1 , one in heterozygous IVS I-110 G>A mutation was located in intron 1 as the $\beta^{+}$mutation type. This situation in thalassemia carriers with high $\mathrm{HbF}$ may be related to mutation types. ${ }^{28,29}$ These suggest that the $\mathrm{HbF}$ level may be associated with the mutation type in some of the BTC patients. The results found in those with the most common IVS-I 110 mutations also mark the effect of other factors.

There are many studies on $\beta$ thalassemia mutations in the world. In a study by Talmaci et al. ${ }^{30}$ on the Romanian population, IVS I-110 was the most common mutation with $31.25 \%$, followed by Codon 39 and IVS II 745 mutations. In a study by Makhoul et al. ${ }^{31}$ in Lebanon, IVS I-110 mutation was found in $34.2 \%$, IVSI-1 in 15\%, IVS I-6 in 14.4\% , and Codon 29 in $9.6 \%$ their study population.

Even though there are differences in the percentages of patients involved, the IVS I-110 mutation is most frequently seen in the neighboring countries like Greece, Macedonia, Bulgaria, and Syria. While the most common mutation in Italy is CD39, it is IVS II-1 in Iran and Azerbaijan. In Azerbaijan, the determined IVS I-110 ratio is close to IVSII-1. ${ }^{31}$ Tadmouri et al. ${ }^{32}$ detected 31 different mutations, most frequently IVS I-110, in 795 cases in Istanbul, Adana, and Antakya. Other mutations observed are IVS I-6, Cd8, IVSII-745, IVS I-1, IVS II-1 Cd39, -30, Cd5 and -28 in order of decreasing frequency. According to the study of Tadmouri ${ }^{27}$, in the Central Anatolia Region most frequently (52.3\%) IVS1-110 mutation is seen. Topal et al. ${ }^{17}$ reported the incidence rates of IVS I-110 mutation as $63.7 \%$ in Antakya, $68.3 \%$ in Kayseri and $46.7 \%$ in İzmir. The incidence rates of other mutations found in order of decreasing frequency were $18.2 \%$, for IVS I-1, Cd9, IVS I-6, and 6\% for IVS2-1. In Kayseri, incidence rates for IVS I-110 (68.3\%), CD8 (19.5\%), IVS I-10 (46.7\%) were as indicated. In İzmir, IVS I-110 mutations were seen more frequently (46.7\%) followed by $\mathrm{Cd}-30$ mutations $(13.3 \%)(14,17)$. In the study conducted by Öner et al in Turkey, common mutation types in order of decreasing frequency were IVS I-110 (42.5\%), IVS I-6 (18\%), IVSII-1 (11.5\%) Cd8 (7.14\%) Cd 39 (6\%), IVSII-745 (4.4\%), IVS I-1 (2.5\%, $-30 \%$, and $2.2 \mathrm{Cd} 51.1 \%$. While Atalay et al. reported incidence rates of different mutations as follows: IVS I-110 (35.9\%), IVSI-6 (21.6\%), IVS I-1 (13.0\%), IVSII-745 (3.6\%), Cd8 (2.2\%), and IVS II-1 $(1.4 \%) .{ }^{31}$ In this study, we detected 17 different mutations. The most frequent ones in order of 
decreasing frequency were IVS I-110 (46.1\%), IVS I-1 (12.2\%), IVS I-6 (9.8\%) and IVSII-745 (7.3\%). Referring to other mutations, we identified greater regional differences which are compatible with the most common mutation study in Turkey in general. We detected IVS II-745 mutation in $7.3 \%$ of the patients, which is an important Mediterranean mutation. In addition, we did not come across a new regionspecific mutation during the study.

The $70.8 \%$ of the mutations detected in this study were localized in intronic regions. The IVS I-110 is the most common mutation in Turkish population, and creates an exon binding region within introns of the first exon, where it will adhere to the second exon and causes adherence to the area during the formation of RNA. ${ }^{34}$ In a study conducted by Baysal et al. ${ }^{35}$ in the Turkish Republic of Cyprus, in patients with IVS I-110 mutation, levels of $\mathrm{Hb}$ (10.05-13.65 $\mathrm{gr} / \mathrm{dL}), \mathrm{MCV}$ (62.6-76.4 fL), HbA2 (4.15-5.15\%), and HbF (0.05-2.35\%) had been reported as indicated. In patients with IVS-I-110 mutation, Talmaci et al. ${ }^{30}$ stated levels of $\mathrm{Hb}$ (11.5-13.5 gr/dL), MCV (63.3-73.4 $\mathrm{fL}), \mathrm{HbA2}$ (2.5-5.9\%), and $\mathrm{HbF}$ (0-1.7\%) as indicated. In this study, levels of $\mathrm{Hb}(8.0-13.0 \mathrm{gr} / \mathrm{dL}), \mathrm{MCV}(47.5-$ $72.0 \mathrm{fL}), \mathrm{HbA2}$ (3.7-6.7\%), HbF (0.05-2.35\%) were measured as indicated. These findings have suggested that the factors other the phenotype are taking part in determining the phenotypic characteristics.

Heterozygous IVS II-1 (G>A) mutation is an intronic region mutation and in the study of Hattori et al. ${ }^{36}$, levels of $\mathrm{Hb}(9.3-12.6 \mathrm{gr} / \mathrm{dL}), \mathrm{MCV}(63.4-80.4 \mathrm{fL})$, $\mathrm{HbA2}(4.2-5.6 \%)$, and HbF (0.3-1.2\%) had been reported as indicated. This mutation is most often seen in Turkey and then Yemen. We found the incidence in the patients to be $2.94 \%$. In these cases mean $\mathrm{Hb}$ (10.1-13.1 gr/dL), MCV (59.7-50.9 fL), HbA2 (5.85-5.90\%), and HbF (2.54-4.49\%) levels were determined as indicated. Heterozygous IVS I-6 $(\mathrm{T}>\mathrm{C})$ mutation is also an intronic region mutation. In the study of Orkin et al. ${ }^{37}$, in carriers of this mutation, levels of $\mathrm{Hb}$ (9.55-14.35 gr/dL), MCV (64.7-77.3 fL), HbA2 (3.35-4.45\%), and HbF (0.1-2.2\%) had been reported as indicated. In our study, in these cases mean levels of $\mathrm{Hb}$ (10.2-11.5 gr/dL), MCV (61.70$65.10 \mathrm{fL}$ ), HbA2 (3.4-5.24\%), and HbF (0-6.9\%) were also determined. Heterozygous IVS II-745 (C>G) mutation is also an intronic region mutation. In the study of Orkin et al. ${ }^{37}$, levels of $\mathrm{Hb}(9.95-13.05 \mathrm{gr} / \mathrm{dL})$, MCV (64.9-76.5 fL), HbA2 (4.4-5.4\%), HbF (0.4-2.2\%) had been reported as indicated. We detected IVS II-745 mutation in five patients. In these patients levels of $\mathrm{Hb}(9.5-11.1 \mathrm{gr} / \mathrm{dL}), \mathrm{MCV}(55.3-64.9 \mathrm{fL})$, HbA2 (4.4-6.1\%), HbF (0.0-4.0\%) were determined. Three of these patients were accompanied by the heterozygous $\mathrm{C} 31 \mathrm{C}>\mathrm{T}$ mutation. We did not find any significant difference in the erythrocyte indicators of these three cases in which intron and exon mutations were seen in combination. One of the first mutations identified and studied extensively is (CAG-TAG) in codon $39 .{ }^{38}$ This is the second most frequent mutation that causes beta thalassemia in the Mediterranean population and accounts for the majority of $\beta$-thalassemia cases in Sardinia. ${ }^{38}$ In this study, we detected this mutation, which constituted $60 \%$ of mutations in exon 2 , in three patients.

In conclusion, 17 different mutations were detected in BTC children in and around Aydın province. Four most common mutations were heterozygous IVS I-110 G>A, IVS I-1 G>A, IVS I-6 T>C and IVS II-745 mutations. It was thought that these mutations are not solely responsible for the effects of mutations on complete blood count parameters and hemoglobin electrophoresis but other factors are also effective on these parameters. Heterozygous IVS I-6 (T>C), c.316-373 (IVS II-478 C>A), -87 C>T, IVS II 81 C>T mutations were observed in patients with normal $\mathrm{HbA} 2$ levels. Mutations of $\beta^{\circ}$ thalassemia in exon 1 can progress with high $\mathrm{HbF}$ level. It was thought that further studies on mutation analysis performed in patients with normal $\mathrm{HbA} 2$, and increased $\mathrm{HbF}$ levels $(>5)$ will contribute to the literature.

Ethics Committee Approval: Aydın Adnan Menderes University Faculty of Medicine has received approval from the Non-Invasive Ethics Committee (2019/155 decision no 5).

Conflict of Interest: The authors declared no potential conflicts of interest with respect to the research, authorship, and/or publication of this article.

Funding: The authors received no financial support for the research, authorship, and/or publication of this article.

Informed Consent: As this is a retrospective study, informed consent was not obtained. 


\section{REFERENCES}

1. Öney S, Öztürk Z, Küpesiz A, et al. Beta-talasemi taşıyıcılarında beta-globin gen mutasyon tipi ve hematolojik fenotip arasındaki ilişki. Türk Çocuk Hematoloji Dergisi. 2008;2(4):23-8.

2. Gülbay G, Yeşilada E, Aydoğdu i, et al. Malatya'da beta talasemi mutasyonları. İnönü Üniversitesi Tıp Fakültesi Dergisi. 2009;16(4):209-12.

3. Moghaddam EM, Bahrami $S$, Naderi $M$, et al. Xmn 1-158 VG variant in $\beta$-thalassemia intermediate patients in southeast of Iran. Int J Hematol Oncol Stem Cell Res. 2017;11(2):165-71.

4. Thein SL. Structural variants with a beta-thalassemia phenotype. In: Stinberg MH, Forget BG, Higgs DR, Nagl RL (eds). Disorders of Hemoglobin: Genetics, Patophysiology and Clinical Management. Cambridge, Cambridge University Press, 2001;342-55.

5. Cavdar AO, Arcasoy A. The incidence of betathalassemia and abnormal hemoglobins in Turkey. Acta Hematol. 1971;45(5):312-8. https://doi.org/10.1159/000208641

6. Ho PJ. The regulation of $\beta$-globin gene expression and $\beta$-thalassemia. Pathology. 1999;31(4):315-24. https://doi.org/10.1080/003130299104666

7. Beta Talasemi Tanı ve Tedavi Kılavuzu, Türk Hematoloji Derneği, 2011:1-19. Erişim adresi: http://www.thd.org. tr/thdData/Books/94/bolum-viii-beta-talasemi-tanive-tedavi-kilavuzu.pdf

8. Tadmouri GO, Başak AN. $\beta$-Thalassemia in Turkey: a review of the clinical, epidemiological, molecular and evolutionary aspects. Hemoglobin. 2001;25(2):227-39. https://doi.org/10.1081/HEM-100104031

9. Tadmouri GO, Garguier N, Demont J, et al. History and origin of beta-thalassemia in Turkey: sequence haplotype diversity of beta-globin genes. Hum Biol. 2001;73(5):661-7 https://doi.org/10.1353/hub.2001.0075

10. Altay C, Gürgey A. Distribution of hemoglobinopathies in Turkey. Report based on studies conducted at the Hacettepe Children's Hospital and the reviews of other studies. Turk J Pediatr. 1986;28(4):219-9.

11. Başak AN. Moleküler tanı ve yöntemleri. In: Canatan D, Aydınok Y (eds). 3. Uluslararası Talasemi Yaz Okulu \& Avrupa Transfüzyon Tıbbı Okulu. İstanbul, Mavi Kare Reklamcılık Ltd. Şti, 2004;199-206.

12. Oski FA. Iron deficiency in infancy and childhood. New Eng J Med. 1993;329(3):190-3. https://doi.org/10.1056/NEJM199307153290308

13. Haemoglobinopathy Diagnosis. Bain BJ. Oxford, Blackwell Publishing Ltd, 2006;36-138.

14. Aksoy K, Çürük MA, Arpacı A, et al. Beta talasemili bir ailenin mutasyon tipinin dot-blot hibridizasyon yöntemi ile saptanması. ÇÜ Sağıık Bil Der 1992;7:87-91.

15. Arpacı A, Aksoy K, Yüregir GT. Preliminary studies for prenatal diagnosis: incidence and mutation site of beta thalassemia in Antakya, Türkiye. Ann Med Sci 1992;1:103-10.

16. Tanrıverdi K. $\beta$-talasemi mutasyon tiplerinin moleküler düzeyde incelenmesi. Bilim uzmanlığı tezi, Adana: Ç.Ü. Sağlık Bilimleri Enstitüsü, 1993.

17. Topal K. Antakya, Kayseri ve İzmir örneklerinde betatalasemi mutasyon tiplerinin saptanması. Doktora tezi,
Adana: C..Ü. Sağlık Bilimleri Enstitüsü, 1998.

18. Evrensel EE. Kayseri bölgesindeki beta talasemi mutasyon tipleri. Uzmanlık tezi, Adana: Ç.Ü. Tıp Fakültesi Biyokimya AD, 2002.

19. Demir A, Yarali N, Fisgin T, et al. Most reliable indices in differentiation between thalassemia trait and iron deficiency anemia. Pediatr Int. 2002;44: 612-6. https://doi.org/10.1046/j.1442-200X.2002.01636.x

20. Shine JW. Microcytic anemia. Am Fam Physician. 1997;55(7):2455-62.

21. Cook J, Skikne BS, Baynes RD. Iron Deficiency: The Global Perspective. In: Hershko C (ed). Progress in Iron Research. New York, Plenum Pres. 1994;219-28. https://doi.org/10.1007/978-1-4615-2554-7_24

22. Oğuz F, Uzunhan TA, Binnetoğlu FK, et al. Hipokrom mikrositer anemide demir eksikliği anemisi ve talasemi taşıyıcılığı oranları. Çocuk Dergisi. 2009;9(3):116-22.

23. Madan N, Sikka M, Sharma S, et al. Red cell indices and discriminant functions in the detection of thalassemia trait in a population with high prevelance of iron deficiency anemia. Indian J Pathol Microbiol. 1999;42(1):55-61.

24. Rahim F, Keikhaei B. Better differential diagnosis of iron deficiencyanemia from beta-thalassemia trait. Turk J Haematol. 2009;26(3):138-45.

25. Vehapoglu A, Ozgurhan G, Demir AD, et al. Hematological indices for differential diagnosis of Beta thalassemia trait and iron deficiency anemia. Anemia. 2014;2014:576738. https://doi.org/10.1155/2014/576738

26. Cao A, Galanello R. Beta-thalassemia. Genet Med. 2010;12(2):61-76. https://doi.org/10.1097/GIM.0b013e3181cd68ed

27. Altay Ç. The hemoglobinopathy problem in Turkey. Tepecik Eğit Hast Derg. 1993;3(1):1-8. https://doi.org/10.5222/terh.1993.55450

28. Kutlar A, Kutlar F, Gu LG, et al. Fetal hemoglobin in normal adults and $\beta$-thalassemia heterozygotes. Hum Genet. 1990;84(1):106-10. https://doi.org/10.1007/BF00276333

29. Lemsaddek W, Picanco I, Seuanes F. Spectrum of beta thalassemia mutations and $\mathrm{HbF}$ levels in the heterozygous Moroccan population. Am J Hematol. 2003;73(3):161-8.

https://doi.org/10.1002/ajh.10358

30. Talmaci R, Traeger-Synodinos J, Kanavakis E, et al. Scanning of beta-globin gene for identification of betathalassemia mutation in Romanian population. Journal of Cellular and Molecular Medicine. 2004;8(2):23240.

https://doi.org/10.1111/j.1582-4934.2004.tb00278.x

31. Makhoul NJ, Wells RS, Kaspar H, et al. Genetic heterogeneity of Beta thalassemia in Lebanon reflects historic and recent population migration. Ann Hum Genet. 2005;69:55-66. https://doi.org/10.1046/j.1529-8817.2004.00138.x

32. Tadmouri GO. Beta-thalassemia in Turkey: distribution, diversity, evolution and phenotype-genotype correlations. Doktora tezi, İstanbul, 1999.

33. Öner $A F$, Özer $R$, Üner $A$, et al. Beta-thalassemia mutations in the east of Turkey. Turk J Haematol. 2001;18(4):239-42.

34. Özkınay F. Hemoglobinopatilerde genetik patoloji ve moleküler tanı yöntemleri. HematoLog. 2014;4(1):11-23. 
35. Baysal E, Indrak K, Bozkurt G, et al. The $\beta$-thalassemia mutations in the population of Cyprus. Br J Haematol. 1992;81:607-09.

https://doi.org/10.1111/j.1365-2141.1992.tb03000.x

36. Hattori Y, Yamamoto K, Yamashiro $Y$, et al. Three betathalassemia mutations in the Japanese: IVS-II-1 $(G \rightarrow A)$, IVS-II-848 (C $\rightarrow G)$, and codon 90 (GAG $\rightarrow$ TAG). Hemoglobin. 1992;16:93-7.

https://doi.org/10.3109/03630269209005682

37. Orkin SH, Kazazian HH Jr, Antonarakis SE, et al. Linkage of beta-thalassaemia mutations and beta-globin gene polymorphisms with DNA polymorphisms in human beta-globin gene cluster. Nature. 1982;296(5858):62731.

https://doi.org/10.1038/296627a0

38. Takeshita K, Forget BG, Scarpa A, et al. Intranuclear defect in beta-globin mRNA accumulation due to a premature translation termination codon. Blood. 1984;64(1):13-22.

https://doi.org/10.1182/blood.V64.1.13.13 